\title{
Follow The Cash: Lessons For Capstone Business Courses
}

\author{
Donald Mong, Slippery Rock University, USA
}

\begin{abstract}
Capstone business students struggle to understand and interrelate all of the strategies and functions of companies. Yet each of those strategies and functions has the purpose of directly or indirectly producing cash flows for the company. We therefore propose that following a company's cash flows can provide effective lessons for capstone business courses. In this exploratory paper, we examine the importance of cash from three perspectives: the company's, the investor's, and the accountant's. We then examine how emerging accounting movements make following cash flows easier for non-accountants and how capstone business instructors might infuse some follow-the-cash lessons into their classrooms.
\end{abstract}

Keywords: Capstone Business Course; Policy; Strategy; Pedagogy; Cash; Cash Flow; Accrual

\section{INTRODUCTION}

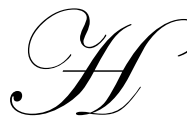

ow does a capstone business instructor cover all facets of business strategies and functions within a single semester? How does (s)he leave students with an understanding of business that is both academically rigorous, yet simple enough to be remembered and used by students in post-graduation job assignments? Can following a company's cash flows help us to do those things?

To answer those questions, we must first understand the overall learning goals of capstone business courses which are taught after students have completed virtually all of their other courses. Mong (2011) identified five such capstone learning goals: to integrate learning across business's functional areas (Arben, 1997, and Eldredge \& Galloway, 1983); to provide the CEO's perspective on managing companies (Denning, 1968, and Bower, 2008); to work within uncertain situations (Denning, 1968, and Eldredge \& Galloway, 1983); to develop and critique strategic models (Schendel \& Hatten, 1972, and Camerer, 1985); and to reinforce a variety of functional skills in students (Hunsicker, 1980, and Gilinsky \& Robinson, 2008).

Achieving the five learning goals within a semester-long course is no easy task. To determine if following a company's cash flows can help us with the goals, we first explore the value of cash from three perspectives. We look at the value of cash to companies, to investors, and to accountants. We begin with the value of cash to companies, and we begin that inquiry with some early entrepreneurial literature. Such literature initially focused on the cash-management techniques of entrepreneurial companies, but later evolved to focus on the value of the cash itself. Such literature also initially presumed that all entrepreneurial companies were small.

\section{THE COMPANY'S PERSPECTIVE}

Grablowsky (1978) compared the cash-management techniques of 66 small companies with those of larger companies. He found that only about $30 \%$ of the smaller companies prepared cash budgets. Grablowsky also investigated the relationship between accruals and accounts payable, finding that only $36 \%$ of the smaller companies understood how to gain cash by negotiating less frequent payments of their accounts payable. Grablowsky thus saw most small companies relying on a series of ad-hoc cash-management decisions. He believed that small-company managers focused on profits rather than on cash flows. 
Grablowsky (1978) opined that the cash management methods of small companies were different than the methods of larger companies. He believed that the methods of larger companies and of college textbooks were too sophisticated for most small business managers to understand. Grablowsky further believed that those methods did not apply to smaller companies because of the instability of small-company customer bases, the scarcity of smallcompany financial talent and data, and the insufficiency of small-company financial resources to overcome cashflow problems even after they were discovered. Grablowsky did see a shift in newer companies toward more highly educated owners and managers and a corresponding shift toward more sophisticated budgeting and cash management practices. Still, had entrepreneurial literature stopped with Grablowsky, cash flows could not have been used as a capstone learning approach for all sizes of companies.

A year later, however, Cooley \& Pullen (1979) found that small companies did well in controlling cash flows and that the cash-management techniques of smaller companies were indeed quiet sophisticated. Cooley \& Pullen surveyed 122 smaller gasoline wholesalers and retailers and evaluated those companies in three areas of cash management. The three areas were budgeting, temporary investing of excess cash, and controlling cash inflows and outflows to maximize cash in the company. Those three areas of cash management were especially important to the gasoline companies surveyed since they generated large amounts of cash and had short cycles between buying and selling their gasoline.

In the first cash-management area of budgeting, Cooley \& Pullen (1979) found that only $28 \%$ of the smaller companies budgeted. Cooley \& Pullen commented on how close their findings were to the $30 \%$ that Grablowsky had found a year earlier. In the second cash-management area of temporarily investing excess cash, Cooley \& Pullen found that a majority of the smaller firms had invested their excess cash, albeit in highly liquid, low-risk investments. In the third cash-management area of controlling inflows and outflows, Cooley \& Pullen found that the smaller companies deposited receivables on the same day received, took advantage of trade discounts for paying their own payables within certain windows of time, and maximized their own cash flows by waiting until the last moment to pay payables.

Govindarajan \& Shank (1986) called cash sufficiency the missing link in all strategic planning, not just in entrepreneurial planning. Govindarajan \& Shank wrote in a time of large conglomerates, corporations composed of many dissimilar business units. Govindarajan \& Shank also wrote when complex strategic modeling was used to analyze those companies. Those models focused on a company's market share and growth rates, rather than on calculating that company's actual cash flows. Govindarajan \& Shank argued that the models of the day had missed the important factor of a company's cash.

Govindarajan \& Shank (1986) defined cash sufficiency as a company having enough cash for the company to grow itself. Govindarajan \& Shank noted that incoming cash flows included internally generated capital, borrowing, and attracting new investors. Outgoing cash flows included maintaining operations and investing in new assets for growth. Govindarajan \& Shank urged companies to calculate sustainable growth rates based on the cash available to the company and to use those rates to make strategic decisions. Nevertheless, Govindarajan \& Shank believed that cash sufficiency alone could not explain all of the strategic choices available to a company and simply sought to include cash sufficiency as one component of the complex strategic models of Govindarajan's \& Shank's time.

Burger \& Hamman (1999), however, made cash a more central component of strategy when they proposed their cash-flow sustainable growth rate (CFSGR). Burger \& Hamman wanted to complement the accounting sustainable growth rate (SGR) that was used by companies to manage their rates of growth in market share, profitability, and inventory turnover. Burger \& Hamman noted that the SGR ignored how much cash the company actually had and could therefore lead to situations where the company seemingly achieved all of its growth goals, but still ran out of cash. The CFSGR, on the other hand, was intended to avoid that situation by tying allowable growth to the maintenance of an acceptable cash balance within the company.

Burger \& Hamman (1999) observed that strategic planners separated strategic goals, which pertained to the long-term viability of the company, from financial goals, which pertained to the shorter-term viability of the company. Burger \& Hamman believed that growth was important to both strategic and financial goals. Burger \& 
Hamman emphasized a company's growth began with its sales, but that sales growth then had to be carefully balanced with the company's financial resources and operating abilities to produce the additional products sold. To achieve that balance, the company's bankers would utilize the sustainable growth rate (SGR) to determine its financing needs and investment opportunities, and the company's managers would utilize the same SGR to balance and prioritize its operating goals. Yet the SGR was based on accruals and therefore missed the needed cash position of the company. Burger's \& Hamman's cash-flow sustainable growth rate (CFSGR) was intended to make sure that the company actually had enough cash to fund its growth, rather than having to wait for its accruals to hopefully turn into cash.

America's change to an entrepreneurial economy (Kuratko, 2003) has only heightened the importance of cash to companies. Opiela (2006) identified cash flow as the single most important factor in the success or failure of entrepreneurial companies. She found that entrepreneurial companies tended to focus on satisfying existing customers when cash was plentiful. Instead, Opiela argued that those companies needed to proactively seek new customers to generate future cash. She cautioned that a month without new clients would mean cash-flow problems for the company three months later.

Opiela (2006) advised start-up companies in particular to focus on the "burn rate" of their cash and to avoid confusing paper profits with hard cash. She cautioned the owners of entrepreneurial companies about using personal assets to bail out their struggling companies. Drawing from financial planners, Opiela advised entrepreneurial companies to conduct liquidity assessments in six areas: operating budgets for monthly inflows and outflows of cash, reserve funds to provide three months worth of living expenses for the company's owner, capital funds to enable the company to grow, dedicated funds for special projects, opportunity funds for taking advantage of opportunities, and contingency funds.

A year later, Jacobides \& Winter (2007) took a more theoretical look at the importance of cash flows to entrepreneurial companies. Jacobides \& Winter found that available cash, not economic synergies, would determine how broad a place in the value chain a given company would seek to occupy. Jacobides \& Winter found that companies would seek to occupy only those narrow parts of the value chain where they obtain the maximum return on their available cash, rather than seeking to occupy all parts of the value chain where each company's innovations might add economic value.

Jacobides \& Winter (2007) defined an entrepreneurial company not by its size, but by its quest to capture extraordinary profit-making opportunities before other companies had found them. Jacobides \& Winter observed that this quest would create considerable cash restrictions for the entrepreneurial company because investors would be reluctant to provide cash for unproven ventures. Thus, the company would seek cash flows wherever they could be found, even in side ventures that were not in the company's core competencies. Jacobides \& Winter used the example of a restaurant owner acquiring adjacent rental properties if the price were right because the rental properties could generate cash. The authors noted that cash was not the only constrained resource in entrepreneurial companies and that the specific constrained resources were unique to each company. Cash, however, was the one constrained resources common to all entrepreneurial companies. Jacobides \& Winter described entrepreneurs as being "rich in ideas and poor in cash."

Bates, Kahle, \& Stultz (2009) soon followed to show the importance of cash to all companies, not just to entrepreneurial ones. Bates, Kahle and Stultz found that the cash-to-assets ratios of U.S. companies had more than doubled between 1980 and 2006. More strikingly, the authors found that the typical company now had enough cash to retire all of its debts. Bates, Kahle, \& Stultz did find that the cash increases were most pronounced in companies that did not pay dividends, in those with recent IPO's, and in those in volatile industries. Nevertheless, the overall trend toward more cash cut across all types of companies. The authors attributed this increased cash in companies to increasing cash-flow risks, falling inventories, falling capital expenditures, and increasing research-and-development expenses.

Bates, Kahle, \& Stulz (2009) believed that the first factor, cash-flow risk, had been intensified because their study had been conducted during a time of increasing entrepreneurship. Entrepreneurial companies were believed to hold more precautionary cash than longer-established companies. Bates, Kahle, and Stulz predicted that cash-flow 
risk would lessen as these entrepreneurial companies matured. However, the authors predicted that the remaining three factors of lower inventory levels, increased research and development, and lower capital assets, would continue to drive higher cash levels in companies. Bates, Kahle, \& Stultz emphasized that trends toward higher research and development and lower hard assets meant that companies needed more cash for self-financing the research and development. This was because fewer hard assets would be available for loan collateral and the incoming cash flows that loans could produce.

In a telling note to the time in which Bates, Kahle, \& Stultz (2009) wrote, they also mentioned that derivatives could alleviate the need for over-cautious holding of cash. After the great recession of 2007, the derivative option has become far less attractive, and perhaps the companies that Bates, Kahle, \& Stulz studied were really maximizing their cash inflows and minimizing their cash outflows because they were becoming scared of that recession. None of that conjecture, however, lessens how important cash flow is to companies.

\section{THE INVESTOR'S PERSPECTIVE}

Cash flow is clearly of importance from the company's perspective, but how important is cash from the investor's perspective? Of what value are cash flows to the investor and to his or her investment portfolio? Estep (1987) found that investment portfolios produced returns for the investor three ways: from equity growths within the investments themselves, from cash flows generated by the investments, and from changes in the perceived market values of the investments. When Estep wrote, portfolio managers were focusing primarily on the third way. They sought to predict what others would think the investments would be worth in the future and then to generate returns by buying and selling on those anticipated changes in perceived value. Estep, however, used mathematical formulae to show that such perceived-valuation changes were actually the smallest producer of portfolio returns. Estep found that over $90 \%$ of Dow Jones portfolio returns in 1985 came not from perceived-valuation changes, but from equity growths and cash flows.

Estep (1987) acknowledged that valuation changes could produce dramatic, short-term returns, but he showed their effect to be neutral over the long term. Estep further observed valuation changes to be volatile and unreliable. Equity growths and cash flows, by contrast, were far more stable, accounting for no losses in returns over the period that Estep studied. Cash flows, the subject of this paper, were the smallest, but most stable component of portfolio returns. Estep found that cash flows and equity growths were inherently complementary since when cash was being used for growth, cash flow naturally declined. Estep therefore advised prudent portfolio managers to maximize returns by balancing focus between both cash flows and equity growths.

Houge \& Loughran (2000) examined the importance of cash flows to investors from a slightly different perspective. Houge \& Loughran investigated the portfolio-return effects of company earnings, accruals, and cash flows. Noting that earnings were simply the sum of accruals and cash flows and finding some division in prior literature on the relative importance of each component, Houge \& Loughran conducted empirical research to see which component actually produced the greatest return for investors. The authors found that component to be cash flows. Houge's \& Loughran's empirical research showed that an accrual-based investment strategy could produce greater returns than an earnings-based strategy, but that a cash-flow-based strategy could produce even greater returns than either of the other strategies.

Houge \& Loughran (2000) believed this phenomenon to be quite logical. They referenced established economic theory that the value of any asset was the sum of the stream of cash flows which that asset could produce, discounted for the length of time before each of those cash flows could be obtained. Thus, current cash flows were far more valuable to investors than any future cash flows resulting from current accruals. Houge \& Loughran noted that other authors, particularly Sloan (1996), had advanced this "cash is king" investment approach. Yet, Houge \& Loughran believed that prior authors had not fully dealt with the differences between cash flows and accruals. Houge \& Loughran observed that firms with high cash flows usually had low accruals, and visa versa, and that superior portfolio returns from cash-based investment strategies were driven by both better-than-average returns from high-cash-flow companies and poorer-than-average returns from high-accrual companies. Houge and Loughran described cash flows as persistent and accruals as transitory and further described high-cash-flow firms as having high-quality earnings that could produce superior returns 
Although he did not cite Houge \& Loughran (2000), Shivakumar (2006) drew similar conclusions. Shivakumar began by citing a number of other studies (Ali, 1994; Pfeiffer et al., 1998; Barth et al., 1999) that showed that cash flows affected stock prices in much greater ways than did accruals. Shivakumar then conducted rigorous econometric testing of all domestic NYSE/AMEX and NASDAQ stocks between 1979 and 1999 to see if this had indeed been the case. Shivakumar focused on calculating expected cash flows from the stocks, comparing them to actual cash flows, and seeing what effect any unexpected cash flows had had on stock prices and on future cash flows. He found that unexpected cash flows affected both stock prices and future cash flows in greater ways than did unexpected accruals.

Shivakumar's (2006) work was econometric. Yet he hoped to lay an empirical foundation for a fuller examination of the relationships between the earnings that were reported on a company's accounting statements and the true value of that company to an investor. That relationship between what accounting statements show and what underlying value they truly represent now transitions us from the value of cash from the investor's perspective to the value of cash from the accountant's perspective.

\section{THE ACCOUNTANT'S PERSPECTIVE}

Schipper \& Vincent (2003) explored the quality of company earnings from the accountant's perspective. Schipper was a member of the Financial Accounting Standards Board (FASB), which formulated the standards that accountants used to produce and audit accounting statements. Schipper \& Vincent opined that the FASB was unlikely to accept any standards that tied the quality of company earnings to their closeness to cash. Schipper \& Vincent believed that a movement to make FASB standards more relevant to non-accountants had led to accountants over-relying on company managers for earnings estimates from incomplete projects. Those estimates, in turn, had allowed managers to manipulate the relative levels of cash and accruals within earnings statements. Schipper \& Vincent thus opined that using the cash component alone to measure the quality of earnings was "not necessarily consistent with a representational faithfulness criterion."

Instead, Schipper \& Vincent (2003) preferred to continue the accountant's historical focus on Hicksian income, the total change in the company's wealth from one reporting period to the next. Schipper \& Vincent defined Hicksian income as the net change in the economic assets of a company over that period of time plus the dividends that the company paid to its shareholders over the same period. The authors believed that both accountants and non-accountant decision-makers were best served by continuing to focus FASB standards on the persistence (sustainability) of earnings, the predictive ability of those earnings, and the variability of the earnings. Without such standards, Schipper \& Vincent argued that managers could manipulate earnings to give investors a preferred picture of smoothly increasing earnings without actually delivering real increases in company value.

Schipper \& Vincent (2003) were not adverse to using cash as one indicator of earnings quality, however, only to using it as the primary indicator. Some of the reasons for Schipper's \& Vincent's reluctance stemmed from limitations in the traditional accounting statement of cash flows. Schipper \& Vincent found that it was hard to categorize many cash flows into the operating, investing, and financing sections of that statement. Nevertheless, the authors acknowledged that cash was more objective and less able to be manipulated than accruals. They also acknowledged that Sloan (1996) had found cash flows to be more persistent than accruals, that Harris (2000) and Penman (2001) had begun to measure the quality of earnings through closeness to cash, and that Dechow \& Dichev (2002) had developed a direct approach to measuring the relationship in earnings between cash and accruals. Schipper \& Vincent even believed that Dechow's \& Dichev's approach was faithful to their own preferred Hicksian approach.

Five years later, some of the authors cited by Schipper \& Vincent (2003) came together as Dechow, Richardson \& Sloan (2008). Dechow, Richardson, \& Sloan believed that prior research had already established the superior persistence (sustainability) of cash over accruals, meaning that companies with earnings composed of more cash and fewer accruals could replicate those earnings over longer periods of time than companies with earnings composed of the reverse. Dechow, Richardson, \& Sloan now sought to explore whether the ways in which companies utilized the cash component of their earnings further affected the quality of those earnings and the resulting value to investors of those companies. 
Dechow, Richardson, \& Sloan (2008) observed that a company's free cash flows could be alternately paid out to investors as dividends or stock repurchases, used to retire company debt, or retained within the company as cash balances. After examining the effects of each alternative on 150,000 firm-years between 1950 and 2003, Dechow, Richardson, \& Sloan found that cash paid out to investors was the most valuable. Dechow, Richardson, \& Sloan offered four conclusions from their research: First, earnings alone were an insufficient benchmark with which to evaluate a company. Second, cash retained by a company for its projects was less valuable than cash paid out to investors or used to retire debt. Third, companies with large accruals had lower earnings persistence and lower future returns to investors than companies with relatively higher cash. Fourth, in valuing a company, cash retained within the company was less valuable than cash paid out. Dechow, Richardson, \& Sloan thus urged investment analysts to focus on the uses of a company's cash flows, not just the amount of those cash flows.

Dechow's, Richardson's, \& Sloan's (2008) advice was sound in theory, but problematical in practice. Hewitt (2009) found that both professional analysts and non-professional investors had trouble even separating cash flows from accruals on current accounting statements. Hewitt tested 74 professional analysts from varied firms and 128 first year MBA students who simulated non-professional investors. He found that both the professionals and the non-professionals did fine as long as cash flows and accruals were similarly persistent (sustainable) in the companies that they were studying, but that both the professionals and the non-professionals struggled when cash flows and accruals were differently persistent. Hewitt cited prior research that had found that up to $40 \%$ of companies had such differing persistence rates in their cash flows and accruals.

Hewitt (2009) believed that reason that both professionals and non-professionals had difficulty with accounting statements was the indirect method by which Financial Accounting Standards Board (FASB) standards required the statement of cash flows to be prepared and presented. He noted that both the Financial Statement Presentation Project the FASB itself had proposed major revisions to those standards. Hewitt quoted the FASB chair as saying that the proposed revisions were intended to have the income statement and the statement of cash flows be used in two distinct ways. The former could continue to be accrual-based with the latter becoming more directly cash-based. Hewitt concluded that both his research and the prior research of Bradshaw et al (2001) and Elgers et al (2003) supported those proposed revisions.

Like companies, investors, and financial analysts, we capstone business instructors are largely dependent on accountants for the financial statements needed to follow a company's cash flows. Follow-the-cash lessons would be of little value if both instructors and students could not easily understand and relate to those financial statements. So what have accountants been doing to make their statements easier to use and more relevant to us non-accountants?

\section{(ALMOST) CASH ACCOUNTING}

Thirteen years before Hewitt (2009), Vent \& Cocco (1996) found that even accounting students had trouble understanding the statement of cash flows. Vent \& Cocco traced this difficulty to the indirect method by which the statement of cash flows had to be derived and to related inconsistencies in Statement of Financial Accounting Standards (SFAS) 95. SFAS 95 excluded certain items from operations on the income statement but including those very same items as operating cash flows on the statement of cash flows. Vent \& Cocco characterized this inconsistency as mixing cash and non-cash items while mixing operating and non-operating items.

Vent \& Cocco (1996) proposed a simplified method of complying with SFAS 95 while generating a statement of cash flows. Vent \& Cocco's method did simplify the process of complying with SFAS 95. Yet even with Vent \& Cocco's simplified method, a student first had to remove all non-operating revenues and expenses from net income and then convert remaining items from accruals to true cash flows. The statement of cash flows continued to be indirectly derived, and that indirect derivation continued to take time, create confusion, and limit the ability of non-accountants to relate given cash flows to the specific company operations that produced them. Despite these limitations, the quest for simpler, more-relevant-to-cash financial statements had begun.

Burger \& Hamman (1999), whose cash-flow sustainable growth rate (CFSGR) we previously studied, also utilized an indirect method of derivation. Recall that Burger \& Hamman developed the CFSGR to help companies 
avoid running out of cash while trying to grow. The CFSGR was intended to complement the accounting sustainable growth rate (SGR) that was based on a company's accruals, rather than on its actual cash flows. Burger \& Hamman derived the CFSGR by simply re-working the three parts of the traditional, indirectly derived statement of cash flows. Burger \& Hamman looked for cash that was either generated or used up first in the company's operations, second in its internal investments, and third in its external debt and equity financing.

Burger's \& Hamman's (1999) primary focus was on a company's growth. They showed that a company's growth in sales had a huge effect on its cash flows. Burger \& Hamman therefore believed that a company's level of sales could sometimes be used as an effective proxy for that company's statement of cash flows. Burger \& Hamman did contrast the details of that statement of cash flows with the accrual-based balance sheet and the accrual-based profits of the income statement. Yet Burger \& Hamman were generally less interested in revising traditional accounting statements than in supplementing them with the CFSGR and occasionally in bypassing them with the sales-level proxy.

It was left to Ohlson \& Aier (2009) to develop a truly direct method of producing accrual-fee accounting statements. Ohlson \& Aier focused on the income statement and proposed a modified-cash accounting (MCA) method of producing that statement. The MCA income statement was to be based on defining cash more broadly than current Generally Accepted Accounting Practices (GAAP) did. The MCA income statement was to rely on common-sense judgments about whether or not each of its own line items was relatively liquid. Ohlson \& Aier emphasized that the MCA income statement could not be derived from the current GAAP statement of cash flows.

Since the MCA income statement itself was to be direct and cash-based, Ohlson \& Aier (2009) asserted that it could overcome much of the confusion created when users of current GAAP statements tried to relate items on the GAAP income statement to items on the GAAP statement of cash flows. Ohlson \& Aier also believed that their MCA income statement could overcome the problems of needing to arbitrarily decide whether individual company transactions belonged in the operating, investing, or financing sections of the GAAP statement of cash flows. Finally, Ohlson \& Aier noted that the MCA income statement provided users with an easy-to-use bottom line with which to evaluate the quality of company earnings, that the MCA income statement provided users with true company growth rates, and that the MCA income statement provided users with true cash values of each of the company's assets, liabilities, revenues, expenses, and customer transactions.

Like Hewitt (2009), Ohlson \& Aier (2009) noted that the Financial Accounting Standards Board (FASB) had begun discussions on revising the current GAAP statement of cash flows through its 2008 Financial Standards Presentation (FSP) paper. Ohlson \& Aier believed that their own MCA approach had advantages over the FSP approach in broadening the definition of cash and in eliminating large numbers of line-item adjustments for the user to move between the income statement and the statement of cash flows. Nevertheless, Ohlson \& Aier found that both the FSP approach and their own MCA approach were similar in being directly derived from cash sales and in having easy-to-use bottom lines at the end of the statements.

Hopefully, such emerging cash-based accounting trends will continue, for they should make following a company's cash flows easier for non-accountants. In the meantime, capstone business instructors have capstone courses to teach, and both instructors and students have widely ranging levels of comfort with current accounting statements. How, then, do we integrate follow-the-cash lessons into our classrooms?

\section{FOLLOWING THE CASH}

Fortunately, following the cash in a capstone business course does not require us to turn every capstone instructor and every capstone student into an accountant. Whether instructors choose to follow a company's cash by delving intensively into accounting statements or by simply dealing with topics conceptually, there are important lessons to be learned.

Recall the five learning goals of a capstone business course: to integrate learning across business's functional areas (Arben, 1997; Eldredge \& Galloway, 1983); to provide the CEO's perspective on managing companies (Denning, 1968; Bower 2008); to work within uncertain situations (Denning, 1968; Eldredge \& 
Galloway, 1983); to develop and critique strategic models (Schendel \& Hatten, 1972; Camerer, 1985); and to reinforce a variety of functional skills in students (Hunsicker, 1980; Gilinsky \& Robinson, 2008).

Following a company's cash flows reinforces accounting and financial skills in students. More importantly, it teaches students to view a company's strategies and functions through the CEO's perspective of what contributions each of those strategies and functions makes to his or her company's cash. That CEO perspective, in turn, provides students with a simple strategic model with which to integrate the many functional business areas and work through business uncertainties.

Thus, following the cash allows capstone instructors to further each of the five capstone learning goals. Within those learning goals are many lessons. We conclude this paper by briefly noting five of the most basic ones. Instructors who choose to utilize the follow-the-cash approach should uncover many more.

\section{Lesson \#1: Integrating Company Functions}

Capstone business students struggle to integrate the many functions of a company, and cross-functional integration is therefore the most basic of all capstone business learning goals. Following a company's cash flows can help students to see how the many functional departments of a company come together in the strategic necessity of producing and conserving cash. Following the cash can make it easier to understand that the value of any one of the departments will largely be determined by how much cash it adds to the company. Following the cash can even help students to understand that their own salaries will largely be determined by how much cash they can add to the company.

Following a company's cash flows can also help us to build a simple strategic model of the company. Recall that Opiela (2006) emphasized that a company's cash flow began with its sales. Certainly, a company can supplement its cash flows by investing excess cash or by selling off assets, but those cash flows are incidental to the core cash flows that a company generates by selling its product to its customers. Burger \& Hamman (1999) noted that a company's cash flows were so directly tied to its sales that sales levels could sometimes be used as a rough proxy for detailed statements of cash flow. Burger \& Hamman further noted that all of a company's other functions had to be carefully balanced with its sales or else the company would run out of cash.

From this simple beginning, we can build our strategic model outward to integrate each of the company's other departments and functions. All of a company's other functions, necessary as they are, simply use or conserve the cash brought in by sales until remaining cash is ultimately paid out to the company's investors. Bates, Kahle, \& Stultz (2009) showed us why some of those functions, like R\&D, use much more cash than other functions. An interesting class exercise is to have each student show how his/her academic major, when translated into his/her future job, adds or subtracts cash from the company. Advertising majors seem surprised to learn that advertising initially decreases the company's cash. Likewise, management majors seem surprised to learn that all that they can do is to conserve cash, not to generate it.

\section{Lesson \#2: Differentiating the Strategic from the Functional}

Capstone business students struggle to differentiate a company's strategic issues, which can put the company out of business, from its everyday functional issues, which can just make the CEO's life miserable. Following a company's cash flows can help students to adopt the CEO's perspective in telling the difference between the two. Ultimately, there is only one thing that can put a company out of business, and that thing is running out of cash. So long as a company has enough cash to continue operating, it can make a myriad of functional mistakes and still stay in business. Staying in business will give the company time to correct those functional mistakes. Once the company runs out of cash, however, it is strategically finished. Thus, seeing whether a given decision would leave the company with enough cash to stay in business if that decision were wrong is one way to identify decisions as either strategic or functional and to prioritize them accordingly.

To reinforce this lesson, capstone instructors can use some of the authors noted in this paper. Recall that Burger \& Hamman (1999) differentiated a company's strategy from its finance (one functional area) by saying that 
strategy concerned the long-term viability of the company, whereas finance concerned the short-term viability of the company. Earlier, Govindarajan \& Shank (1986) called a company's cash flows the key to all of its strategy. Later, Jacobides \& Winter (2007) found that cash flows determined the strategic links on the value chain that a company would seek to occupy.

\section{Lesson \#3: Pleasing Investors}

Capstone business students struggle to understand which projects are best for a company to undertake. Following cash flows can help students to adopt the CEO's perspective on choosing projects. Students have been taught in previous finance courses to determine the best available project for a company through the application of financial formulae. Such formulae are designed to calculate the relative economic value of alternative projects which the company might undertake and then to guide the student to selecting the alternative with the highest economic value. Unfortunately, much of that economic value might initially be in accruals, rather than in actual cash.

The CEO's perspective, on the other hand, is to please investors. Investors want immediate cash flows. Estep (1987), Houge \& Loughran (2000), Shivakumar (2006), and Dechow, Richardson, \& Sloan (2008) all found that a company's cash flows drove that company's value to investors. In particular, Dechow, Richardson, \& Sloan found that it was the cash paid out to investors that created the very highest company values. If CEO's are to have cash to pay out, then they need to choose projects that produce the greatest cash flows the quickest, rather than projects that might have the highest overall economic value.

\section{Lesson \#4: Differentiating Entrepreneurial Management from Established-Company Management}

Capstone business students struggle with the differences between entrepreneurial management, about which they have heard so much, and established-company management, about which so much of their business education continues to be focused. Following cash flows can help students to work through the uncertainties of future jobs by teaching them some of the differences and some of the similarities between entrepreneurial management and established-company management.

Opiela (2006) emphasized that entrepreneurial companies are driven by cash, not by profits. She also noted how quickly entrepreneurial start-ups burn through their initial cash reserves and how tempting it is for entrepreneurial owners to intermingle company and personal cash. Each of those issues is very different for larger, established companies. For example, established businesses do worry a lot about profits since profits are what are reported on accounting statements for investors to see. With larger cash reserves at their disposal, established companies also worry less about burn rates and about the need for investors to provide personal assets to the company.

Jacobides \& Winter (2007) described entrepreneurial companies as being rich in ideas, but poor in cash. Those constrained resources lead to differing managerial approaches between entrepreneurial and established companies. Grablowsky (1978) and Cooley \& Pullen (1979) both found that only $30 \%$ of entrepreneurial companies budgeted. While that number has undoubtedly increased with today's financial software packages, the fact that entrepreneurial managers must adopt a more intuitive management style than established-company managers remains. Also remaining is the fact that entrepreneurial employees must wear a lot of hats. Even if their primary responsibilities are outside of finance, capstone students who anticipate careers in entrepreneurial companies must be able to quickly reach for tools like Burger's \& Hamman's (1999) cash-flow sustainable growth rate to help their companies on given projects.

Still, as Bates, Kahle, \& Stultz (2009) showed us, there are also similarities between entrepreneurial and established-company management. Even large corporations are cutting inventories and hard assets today and increasing their research and development, just as entrepreneurial companies have always had to do. 


\section{Lesson \#5: Understanding the Limits of Accounting Statements}

Both capstone business students and more than a few capstone business instructors struggle to interpret accounting statements. Yet accounting is the language of business, and capstone business students must master it to be successful in future careers. Following a company's cash flows can help students to reinforce previously learned accounting skills and to focus on the most important information in accounting statements.

Following a company's cash flows can also help students to understand that accountants and managers read financial statements differently because accountants and managers have differing uses for the statements. As Schipper \& Vincent (2003) noted, accountants fear the manipulation of company earnings by managers. Accountants will thus be reluctant to change accounting statements that were designed in part to prevent such manipulation. Schipper \& Vincent spoke for many accountants when they expressed a preference for continued focus on Hicksian wealth in accounting statements and for continued emphasis on the persistence (sustainability), predictability, and non-variability of earnings. Accruals will thus continue to be a large part of accounting statements, and both students and managers will have to continue to struggle with the indirectly derived statement of cash flows.

Nevertheless, capstone business students can take heart from Vent's \& Cocco's (1996) finding that even accounting students have trouble with the statement of cash flows. Capstone business students can also take heart from Hewitt's (2009) finding that even professional financial analysts have trouble locating cash flows on current accounting statements. Most importantly, capstone business students can take heart that they themselves now know to look for emerging tools like Ohlsen's \& Aier's modified cash accounting statement to locate the cash flows that others might miss.

\section{CONCLUSION}

Not every lesson that should be taught in a capstone business course can be taught by simply following cash flows. Still, cash flows are of such critical importance to business, whether from the perspective of the company, the investor, or the accountant, that cash flows reach across many of those lessons and help us to unify them. Teaching students to follow cash flows can help them both in capstone business courses and in the careers that follow graduation.

\section{AUTHOR INFORMATION}

Donald Mong is an Assistant Professor of Law \& Entrepreneurship at Slippery Rock University of Pennsylvania and has taught capstone business courses there. E-mail: donald.mong @ sru.edu

\section{REFERENCES}

1. Arben, P.D. (1997). The integrating course in the business school. Business Horizons. 40(2), 65-70.

2. Bates, T.W., Kahle, K.M., \& Stultz, R.M. (2009). Why do U.S. firms hold so much more cash than they used to? Journal of Finance, 64(5), 1985-2021.

3. Bower, J. (2008). The teaching of strategy: From general manager to analyst and back again. Journal of Management Inquiry, 17(4), 269-275.

4. Burger, J.H. \& Hamman, W.D. (1999). The relationship between the accounting sustainable growth rate and the cash flow sustainable growth rate. South African Journal of Business Management, 30(4), 101, 9 p.

5. Camerer, C. (1985). Redirecting research in business policy and strategy. Strategic Management Journal, 6(1), 1-15.

6. Cooley, P.L. \& Pullen, R.J. (1979). Small business cash management practices. American Journal of Small Business, 4(2), 1-11.

7. Dechow, P.M., Richardson, S.A., \& Sloan, R.G. (2008). The persistence and pricing of the cash component of earnings. Journal of Accounting Research, 46(3), 537-566.

8. Denning, B.W. (1968). The integration of business studies at the conceptual level. Journal of Management Studies, 5(1), 1-28. 
9. $\quad$ Eldredge, D.L. \& Galloway, R.F. (1983). Study of the undergraduate policy course at AACSB-accredited universities. Strategic Management Journal, 4(1), 85-90.

10. Estep, T. (1987). Manager style and the source of equity returns. Journal of Portfolio Management, 13(2), 4-10.

11. Gilinsky, A. Jr. \& Robison, R. (2008). A proposed design for the business capstone course with emphasis on improving students' information competency. Journal of Management Education, 32 (4), 400-419.

12. Govindarajan, V. \& Shank, J.K. (1986). Cash sufficiency: The missing link in strategic planning. Journal of Business Strategy, (7)1, 88-95.

13. Grablowsky, B.J. (1978). Management of the cash position. Journal of Small Business Management, 16(3), 38-43.

14. Greiner, L.E., Bhambri, A., \& Cummings, T.G. (2003). Searching for a strategy to teach strategy. Academy of Management Learning \& Education, 2(4), 402-420.

15. Hewitt, M. (2009). Improving investors' forecast accuracy when operating cash flows and accruals are differentially persistent. Accounting Review, 84(6), 1913-1931.

16. Hodgetts, R.M., Ezell, D.E., \& Van Auken, P.M. (1976). A contingency approach to business policy pedagogy. Academy of Management Proceedings, 1976, 130-134.

17. Houge, T. \& Loughran, T. (2000). Cash flow is king? Cognitive errors by investors. Journal of Psychology \& Financial Markets, (1(3/4), 161-175.

18. Hunsicker, J.Q. (1980). Can top managers be strategists? Strategic Management Journal, 1(1), 77-83.

19. Jacobides, M.G. \& Winter, S.G. (2007). Entrepreneurship and firm boundaries: The theory of a firm. Journal of Management Studies, 44(7), 1213-1241.

20. Kuratko, D.F. (2005). The emergence of entrepreneurship education: Development, trends, and challenges. Entrepreneurship: Understanding and Practice, 29(5), 577-597.

21. Leontiades, M. (1979). Strategy and reality: A challenge for business policy. Academy of Management Review, 4(2), 275-279.

22. Mong, D. (2011). Goals and learning objectives for capstone business courses. Journal of the Northeastern Association of Business, Economics, and Technology, 17(1), _.

23. Ohlson, J.A. \& Aier, J.K. (2009). On the analysis of firms's cash flow. Contemporary Accounting Research, 26(4), 1091-1114.

24. Opiela, N. (2006). Keeping small business cash flow on track. Journal of Financial Planning, 19(7), 26-32.

25. Schendel, D.E. \& Hatten, K.J. (1972). Business policy or strategic management: A broader view for an emerging discipline. Academy of Management Proceedings, 1972, 99-102.

26. Schipper, K. \& Vincent, L. (2003). Earnings quality. Accounting Horizons, 2003 Supplement, 17, 97-110.

27. Shivakumar, L. (2006). Accruals, cash flows, and the post-earnings-announcement drift. Journal of Business Finance \& Accounting, 33(1/2), 1-25.

28. Vent, G.A. \& Cocco, A.F. (1996). Teaching the cash flows from operations section of the statement of cash flows under the indirect method: A conceptual framework. Journal of Education for Business, 71(6), $344+$. 


\section{$\underline{\text { NOTES }}$}

